\title{
Population Study of Japanese Monkeys at Takasakiyama I*
}

\author{
K. Masui, A. Nishimura, H. Ohsawa and Y. Sugiyama
}

\section{Kyoto University}

\begin{abstract}
Population censuses of Japanese monkeys at Takasakiyama were taken three times from 1970-1972. Because the population has become very large confirming exact troop sizes presents many practical problems. This paper, the first in a series of reports on demography at Takasakiyama, describes the methods used in the census, giving population size and age-sex compositions of these unusually large troops. Provisioning began at Takasakiyama in 1953. The Takasakiyama troop split three times since then, and four troop were made. The fourth troop was trapped and removed after the last division. The first three troops, A, B, and C, now have populations of 880-900, 250-260, and 250-260 respectively. Over the twenty years since provisioning began the size has increased $61 / 2$ times, from 220 to 1400 individuals. These are the largest troops of non-human primates known to exist, and the population is still increasing linearly.
\end{abstract}

\section{INTRODUCTION}

Three population censuses of Japanese monkeys were taken at Takasakiyama in December 1970, September-October 1971, and January 1972. Although intensive field studies have been focused on the sociology of Takasakiyama since provisioning began, our purpose was to obtain demographic data on the Takasakiyama population to be used not only for ecological or sociological studies but also for population genetics or other studies on Japanese monkeys.

As of 1969, there were about 1250 monkeys at Takasakiyama, nearly all of which were divided into three troops called A,

* This study was financially supported by The Cooperative Research Fund of The Primate Research Institute, Kyoto University and Oita City.
$\mathrm{B}$ and $\mathrm{C}$, the sizes being about 800,220 and 200 , respectively. There were also about 30 males apparently belonging to none of these troops (Nishimura, 1969). All these troops, and especially Troop A, are considerably larger than other known Japanese monkey troops. Typically, Japanese monkey troops consist of from 30 to 80 individuals, and may not always exhibit a complete age distribution. It is difficult to get sufficient demographic data for quantitative analysis from such small troops. Data for significant statistical analysis of populations may more easily be obtained from large troops than from small ones.

On the other hand large troops present practical problems, for gathering data. Accuracy in counts of troop size, births, deaths, immigrations and emigrations is very difficult. For many years systematic 
and regular population censuses were abandoned at Takaskiyama. We began our long-term project in order to get precise and systematic data on population dynamics.

These studies are divided into two categories. First, we analyzed the dynamics of size and age-sex composition of each troop by annual census. Second, we collected data on certain known individuals by means of continuous observation.

This report is primarily a discussion of methodology and the practical problems of census-taking in large troops. It is the first in a series of reports on our demographic studies.

It was essential to know the condition of the monkey population at Takasakiyama, and to be aware of future plans of the Takasakiyama National Park for the management of the troops. Our census was organized and executed with the cooperation of Oita City, the managing authority at the Park. Twenty-two researchers and park employees who were interested in the Takasakiyama population participated in the census*. Without the assistance of these people, the census could not have been successfully carried out. The authors would point out that the planning, execution, and analysis of this large task was the work of many devoted individuals.

I. Population census

* the names of participants are as follows; J. It ani, H. Mizuhara, K. Nozawa, T. ShotaKe, T. Enomoto, F. Fukuda, S. TANAKA, H. Shin, S. Ando, Y. Shin, K. Kawai, H. Himeno, T. Fusamae, T. Hoshino, H. Kojo, H. Ito, K. NAKATANI, T. ONO, K. KADOWAKI, S. Ninomiya, C. NAKano, and M. Ando. a) A Short History of Population Studies Dr. Junichiro ITANI first counted the Takasakiyama troop in October of 1950 (ITANI, 1954). He counted the monkeys as they passed through the small Tsubakidani valley. He estimated the troop size to be 170 at that time. He took a second census during April and May of 1953 (ITANI, 1954), and by the same method determined troop size at 220 animals. At this time he also obtained data on troop composition.

Population size since 1953 has been estimated by adding the number of births each year to the 1953 data, and subtracting the number of confirmed deaths, immigrations, or forced removals. Estimated population sizes came out larger than actual sizes because numerous unidentified individuals, especially immatures, died or left the troop and were not deducted from the total numbers.

ITANI and others (1963) took a census in December 1962 by the marking method. They applied lacquer paint to the body of every monkey checking sex, age, identity, etc. At that time, they estimated the total population to be 775 , while the estimation from adding and subtracting the 1953 data was 920 individuals. In December 1965 ITANI and others (ITANI et al., 1966, Sugiyama, 1966) tried another census using paint. These results were not as good as the 1962 marking census, because many monkeys showed a strong aversion to being painted. Nishimura took a census with CARPEnter in September, 1966 (NishimURA 1966, CARPENTER \& Nishimura, 1966) and again, alone, in 
September 1969 (Nishimura, 1969). He used the method of "procession counting" as ITANI had done before him in 1950 and 1953. In these more recent censuses, agesex composition was not clear and even troop size was only roughly grasped. However, it proved from these censuses that procession counting, if properly adapted, could still be used to make fairly accurate population censuses of such ultra-large troops as those at Takasakiyama today. The method used in this most recent census series was an adaptation of procession counting.

b) Methods

\section{Procession Counting.}

Many field workers count the size and composition of wild monkey groups by checking off animals as they move through an area allowing optimal observation. At Takasakiyama, however, each of the troops moves in a massive procession measuring hundreds of meters in length and measuring more than 50 meters across. For example the width of Troop A while traveling was not less than 150 meters and it required more than one hour to pass through a checking lines. It is hardly possible for one observer to count the number of animals in these troops. We devised the following method of procession counting.

We familiarized ourselves thoroughly with the patterns, routes, and times of movement for each troop in a given season. We selected check points allowing the best visibility. Often these check points had to be cut out of surrounding growth and bushy trees.
Each of five to twelve observers was given his own position on a line of check points which were at right-angles to the predetermined traveling route. Spaces between the observers, who were facing in the same direction, varied from five to thirty metres according to the conditions of visibility or the clumping of the monkeys' movements.

As the monkeys passed by, the observers standing on the checking lines counted and recorded them. Observers attempted whenever possible to record the name, age, and sex of each individual. The time and place where the monkeys passed and how they crossed the checking line were also recorded, though these things could not always be checked off accurately when a large number of animals crossed through a check point area in a short time.

Age Classification.

From physical appearance or behavior, it is usually not difficult to judge the age of monkeys three years old and under. In practice, however, accurately judging age even of these immature monkeys was not easy, as it had to be done very quickly. Descrimination of sex in these immature animals was also very difficult to do quickly. For monkeys older than 4 years, sex was easy to discriminate, but age became much more difficult to accurately estimate. Because of these difficulties, it was efficient to arrange age-sex compositions into the following 14 or less categories. Yearly infant males and females are described as

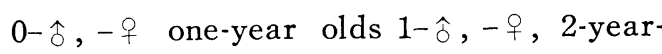

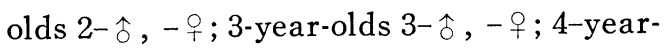
olds $4-\hat{o},-q$; young adult male ( $5-7$ years 
old), $\mathrm{Y} \hat{\delta}$; young adult female (5-6 years old) $\mathrm{Y}_{5}$; adult male (more than 7 years old), A $\hat{o}$; adult female (more than 7 years old), A 우. Male monkeys grow rather linearly in weight and length up to 7 years, with growth stopping at about 8 years when the face and hips become bright scarlet and they are easily distinguishable from immatures. On the other hand, most females have their first babies at 5 or 6 years. Females from 7 years up were classified as fully adult, for convenience in calculations of the birth rates.

The population census was carried out during the following three periods.

1st December 17-29, 1970

2nd September 21-October 3, 1971 3rd January 4-15, 1972

The first and third censuses came during the mating season and the second census came at the end of the birth season ( $\mathrm{KA}^{-}$ WAI et al., 1967).

\section{Practical Precautions}

Careful attention was paid to potential difficulties in setting up our procedures. The checking line had to be longer than the width of the troop at any time. Every observer had to be able to record all monkeys that passed through his checkpoint. The checkpoints had to be a sufficient distance from the feeding ground, otherwise animals might slow down and linger without passing through. Furthermore it was necessary to pay special attention to

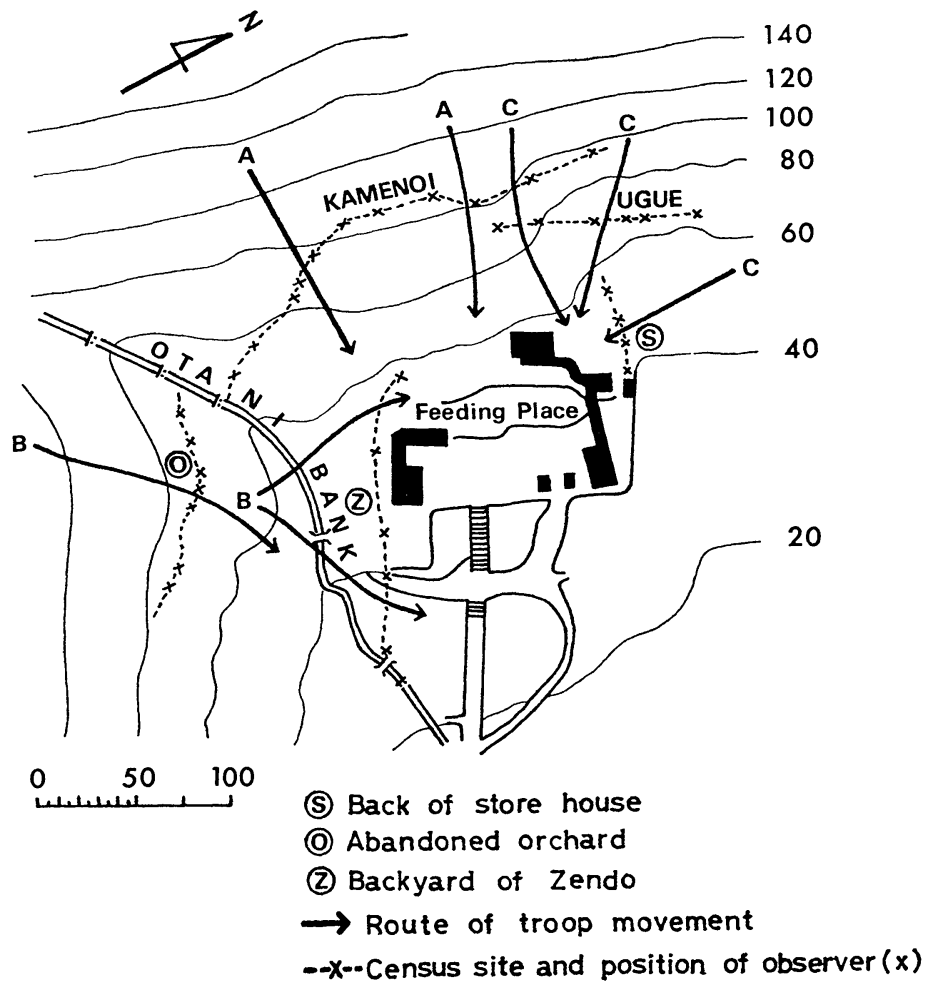

Fig. 1. Census site at Takasakiyama. 
the spacing of the observers. The distance between observers had to be narrowed at the central areas of the troop procession. Since the distribution of individuals in a progression varied from day to day, we had to be able to quickly adapt to any changes in the monkey's movement.

Troop movements at Takasakiyama are fairly regular compared with other troops. Their movements have been well studied, so it was relatively easy to become familiar with their movement patterns and to select a good site for our checking line. The Takasakiyama troops have long been accustomed to human contact, so that we felt that the presence of numerous observers would do little to distort their movements. Nevertheless we did not get satisfying data on several occasions because we misjudged the travel route of the troops, and for various other reasons.

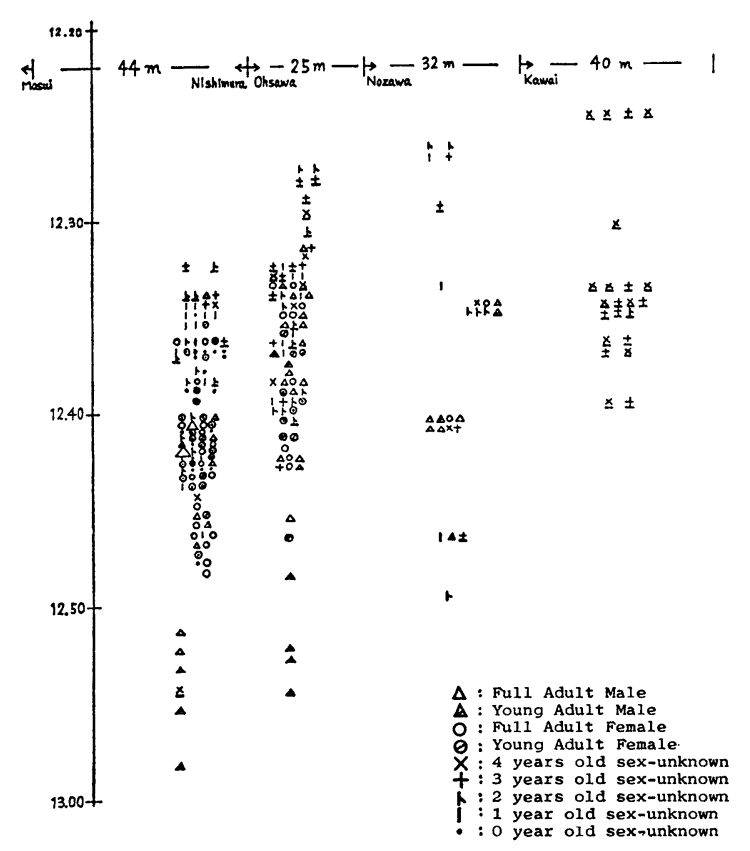

Fig. 2. Individual distribution in procession.
The main routes used by each troop when they come to the feeding ground and the checking places for the censuses are shown in Figure 1. Kamenoi slope was chosen as the checking line for the census of Troop A, about 150 metres above the feeding ground. The backyard of Zendo, the bank of the Otani valley and the Abandoned Orchard were chosen for Troop B. The back of the storehouse and Ugue Steep were selected for Troop C.

Usually Troop A arrives at the feeding ground at about $7: 00$ to $8: 00$ a.m. After they have fed they move away, and Troop $\mathrm{C}$ comes. After troop $\mathrm{C}$ feeds and moves on, Troop B comes. Troop members travel in a denser mass when they are approaching the feeding ground. At other times their mass is more dispersed. We chose to count them when moving in this denser mass.

Figure 2 shows an example of the dispersion of individuals in a traveling troop. We used this configuration to ascertain whether or not the length of the checking line coverd the troop sufficiently.

II. Troop size and age-sex composition

Procession counting was carried out repeatedly as follows: 5,10 and 8 times for Troops A, B and C respectively in December, 1970, and five times for each of three troops in September to October, 1971, and 8, 5 and 3 times in January, 1972. Other attempts at counts were made, but sometimes the monkeys did not pass through the checkpoints properly, so that data 
Troop A (Sept.-Oct. '71)
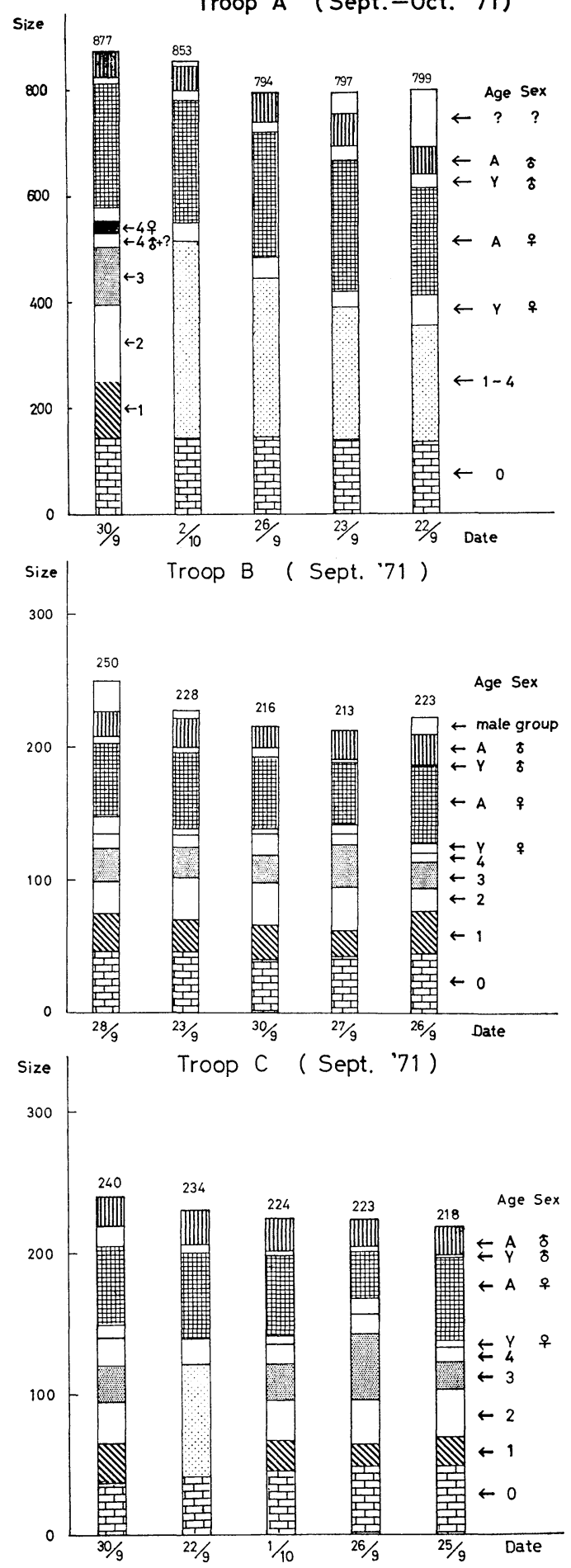

Fig. 3a. was incomplete and was not included.

The troop numbers obtained by procesaion counting differed at every attempt. The range of variation was, as in the second period of census, 797 to 877,210 to 227 and 218 to 240 for troops A, B and C respectively. The smaller the number, the greater the possibility that some monkeys passed uncounted. How can we account for these discrepancies?

For troop A, there was a general tendency to count fewer animals in the early census attempts (Fig. 3). This might mean that observers need several days to become accustomed to the counting of troop A, so that the earlier counts were less accurate.

There are two additional considerations. First, some monkeys move apart from the main part of the troop. Males, especially those three to seven years old were sometimes observed, either singly or in groups, moving far distant from the other members of the troop. We noted that the first and third censuses were made during the mating season. Often male-female consort pairs did not move with the rest of the troop.

A second factor which caused miscounts was the uneven distribution and moving patterns of the troops. It sometimes happened that some checkpoints had a very extreme concentration of monkeys moving very quickly, both on the ground and through the trees overhead. Inevitably, some individuals passed uncounted, despite all our attempts to situate observers where they could see as much as possible.

The size of age-sex categories differed considerably in each count, even when the 

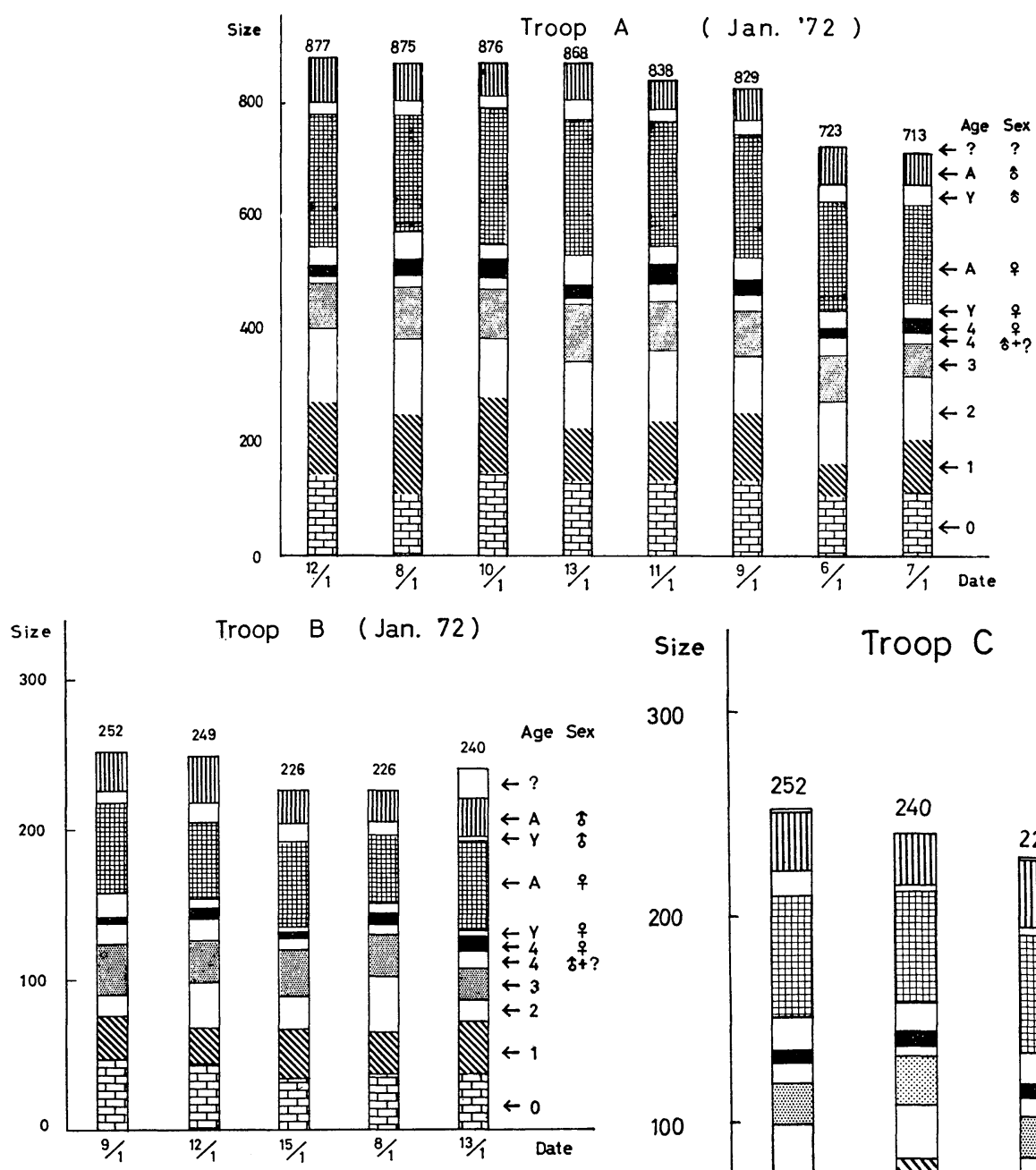

Fig. 3b.

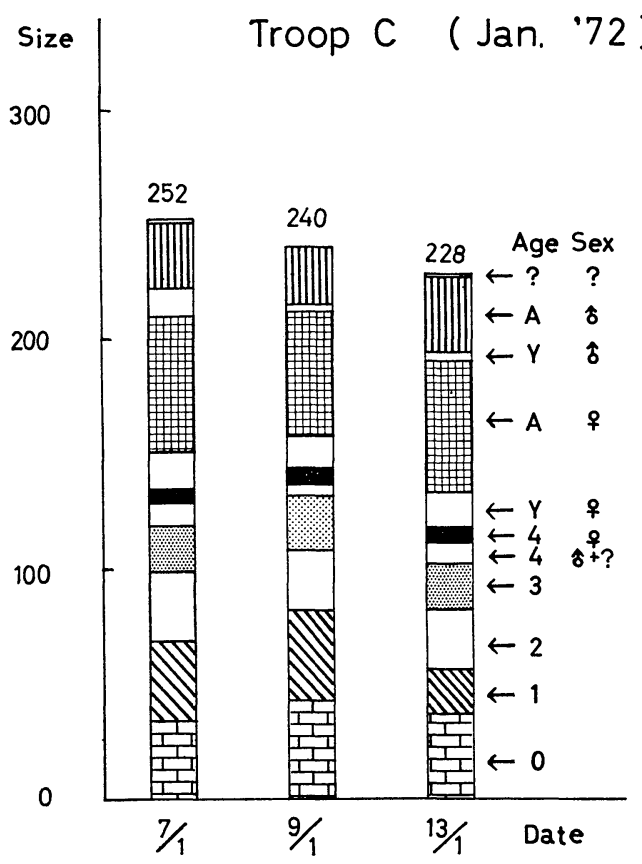

Size and age-sex composition of troop in each census. Size of each age-sex category is proportional to the area.

large troop counts did not differ greatly ring observational judgements among ob(Fig. 3). Such differences in the size of servers. We estimated the size of the age-sex categories are due mainly to the troops and the size of individual age-sex difficulties of discriminating exact age categories by the following procedure. classes in many individuals, and to diffe- 1. In order to correct for such an observer 


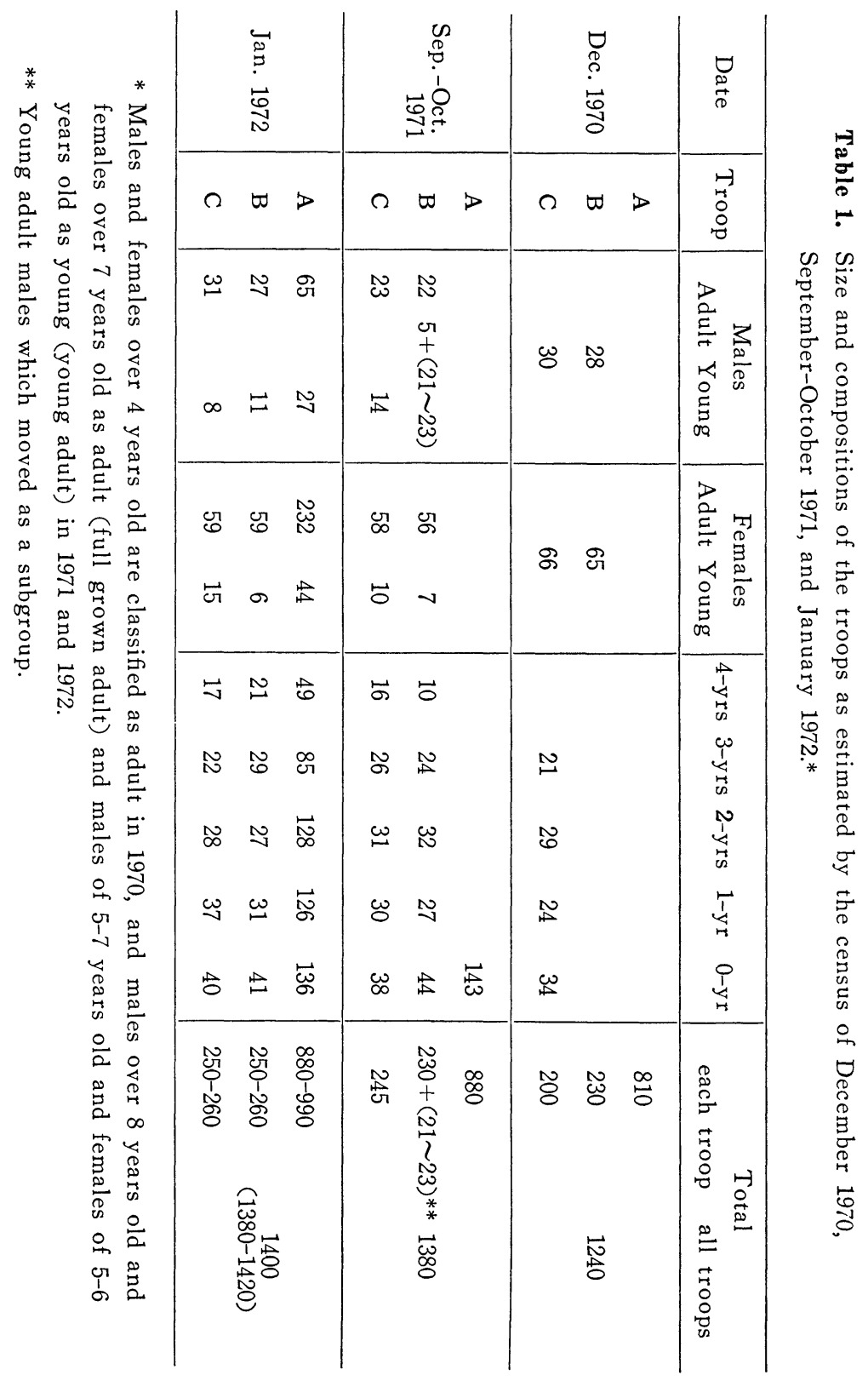


error as individuals not counted, the largest total or a little more than that was used for the actual size of each troop.

2. Accurate judgements of the age-sex category of some animals were not always possible. There was also some chance that individuals were not counted. Hence, we determined the size of each age-sex category by eliminating the largest and the two smallest counts. Then we took the average of the remaining totals size of the remaining totals as the size of each age-sex category.

3. We excluded from our final calculations the two smallest counts of Troop $\mathrm{C}$ taken in the first census period and those of Troop $\mathrm{A}$ in the third census period, as they were unusually small.

4. The second census period came just after the birth season. We counted the

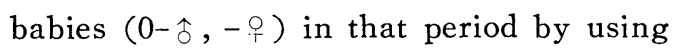
the birth records and by noting the disappearance of any of the recorded births.

5. Unfortunately the counts of Troops A and $B$ during the first census period and of troop A during the second period were too rough for determining the composition of each age-sex category, except babies.

6. Although judgement of the age-sex categories of adult/young adult male must have been always correct, in order to account for possible separate movement of males away from the troop, we eliminated only the two lowest counts of these two categories before arriving at the final figure by the average size.

The results of the above estimates are shown in Table 1, and in Figure 4. From Table 1 it should be noted that due to the 1971 births, troop size was actually larger in all troops. Comparing the results of the second and third censuses it can be said that the troop size is slightly bigger in the third census. The second census was taken at the end of the birth season, and only two infants were born between the second and third census. On the other hand 13 monkeys (9 adult/young adult males and 4 adult females) were captured by Oita City between the second and third

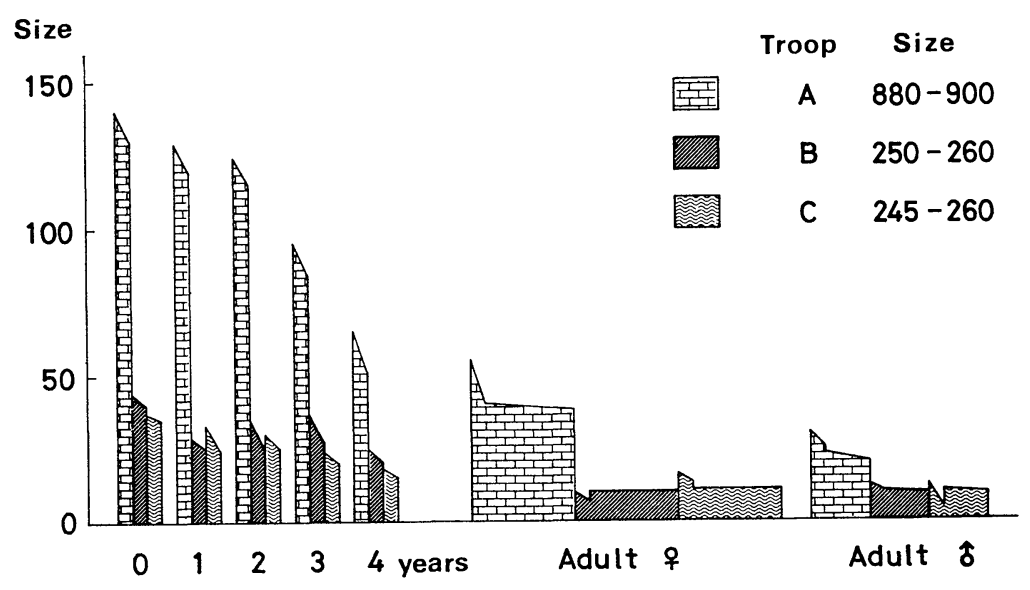

Fig. 4. Size and composition of troops in January, 1972. 


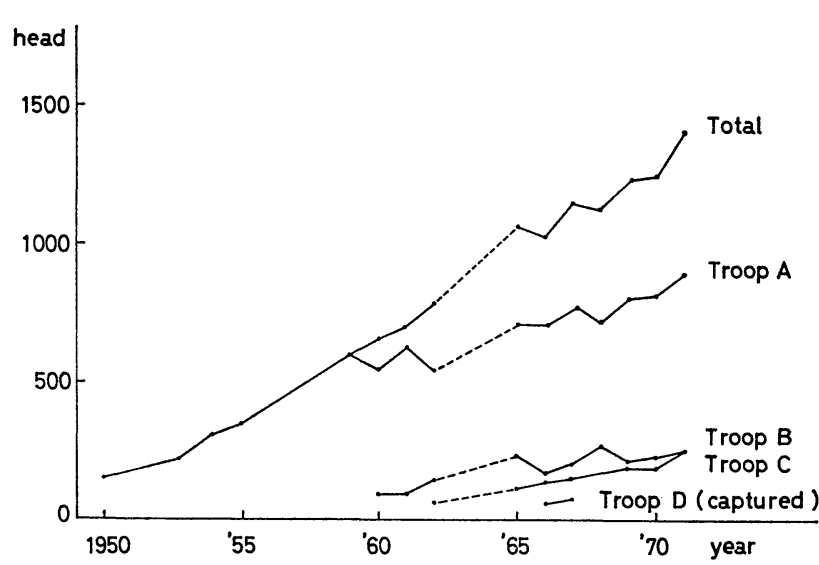

Fig. 5. Population growth at Takasakiyama.

with the data gathered on the numbers of monkeys before 1970 , we can show the population increase of the Takasakiyama monkeys (Fig. 5). The population grew from 220 in April, 1953(ITANI 1954)* to about 1400 for the three troops, an increase of about six and a half times over 20 years. Figure 5 shows that the population still shows a linear increase.

About 2500 monkeys were born

census. The increase in troop population from the second census to the third is due to the immigration of new monkeys into the troops. Previous observations have shown these new individuals to be exclusively males. Differences in the size of various age-sex categories between the censuses may be result of observer error in accurately estimating age during procession counting. These errors may occur because monkeys look older in the mating season than in other seasons.

III. Population changes at Takasakiyama

Combining the results of our censuses

* In 1953, just after provisioning began, the population of the original troop was 220 . Assuming ITANI's estimation to be correct, the rate of increase was the same before and after the provisioning.

** Author's Address: Ken'ichi Masui, Dept. of Zoology, Faculty of Science, Kyoto University, Sakyo, Kyoto 606, Japan; Akisato Nishimura, Hideyuki OHSAWA and Yukimaru SugIYAMA, Kyoto University Primate Research Institute, Inuyama, Aichi 484, Japan. during the past 19 years at Takasakiyama (Table 2). The total number in 1971 is about 1400 and the population when the troop was first provisioned was about 220 . Thus around 1300 have died, left the troop or been captured over the last 20 years. There are 204 recorded captures for the 20 year period (Table 3 ).

\section{Future problems}

In order to analyze the population growth of the Japanese monkeys at Takasakiyama, precise population censuses must be carried out at 3 to 5 year intervais. In previous data, age composition, emigrations, and immigrations of males were not accurate. The present project includes continuous observations on certain marked individuals. We hope to provide sufficient data on these individuals for analysis of age composition, and movement in and out of the troops.

The results of future censuses will be regularly reported. 
Table 2. Birth record at Takasakiyama 1950-1971.

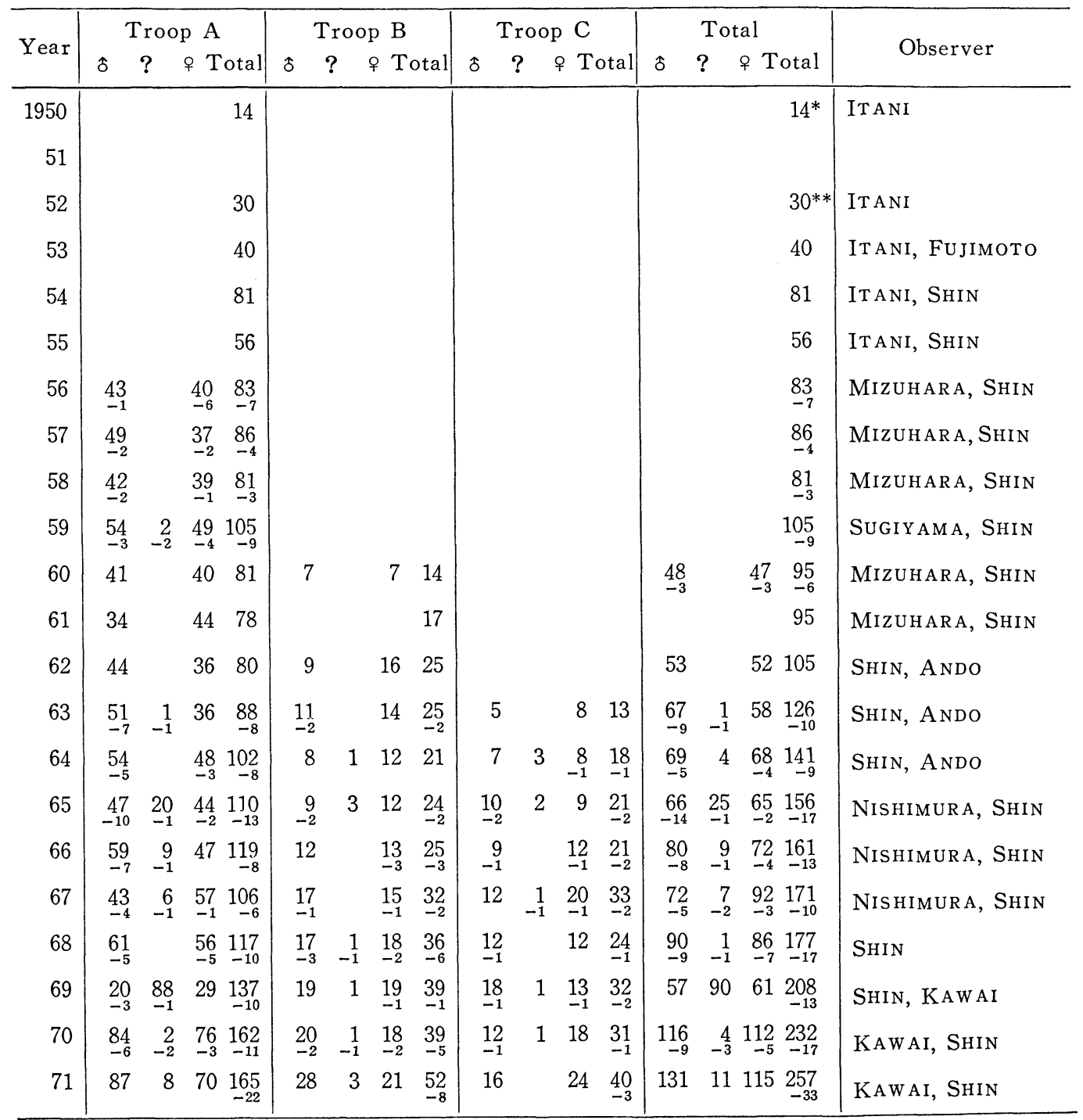

Small figure is the number of still-birth and death within a few month when the infant is highly depend on its mother.

* Estimation based on the observation of troop procession one month after the end of birth season.

** Estimation made seven to eight months after the end of birth season. 
Table 3. Record of animals removed from Takasakiyama.

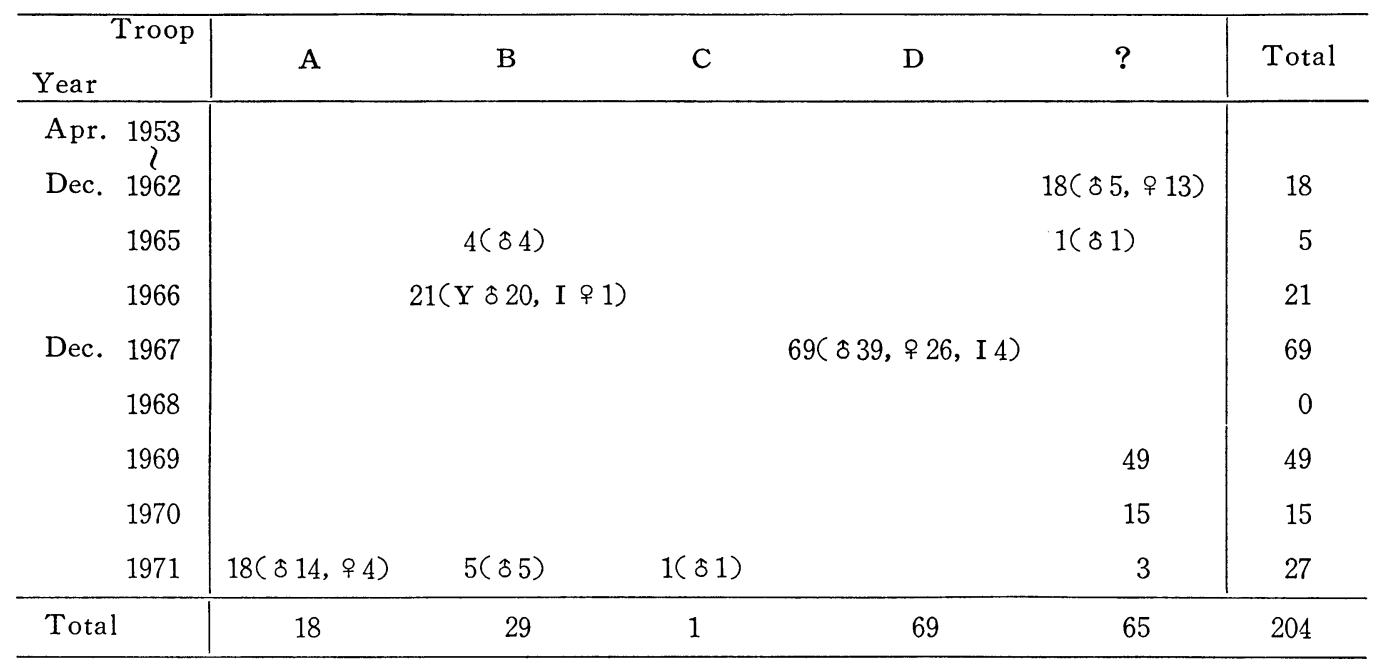

Though exact record was not gotten, some monkeys must have been caught and removed in betwee 1963 and 1965. Some monkeys other than troop D member had been captured in 1967.

\section{REFERENCES}

Carpenter, C. R., 1967: Suggestions for the development of the Takasakiyama Reservation and Primate Colony. (Presented to Oita City) \& A. Nishimura, 1968: The Takasakiyam, solony of Japanese Macaques (Macaca fuscata). Proc. 2nd Int. Congr. Primat., 1: 16-30. \& 1968: Characteristics of Colony of Japanese Macaques ( $M a$ caca fuscata). Proc, VIIIth Congr. Anthrop. Ethnol. Sci. I : 256-258.

IT ANI, J., 1954: Japanese monkeys in Takasakiyama. Kobunsha 284pp.

\& H. Mizuhara, 1957: Notes on malformed individuals found in the wild group of Japanese macaques at Takasaki yama.Bull. Exp. Anim. 6(4) : 105-107.

K. TOKUdA, Y.FuruYa, K. KANo

\& Y. SHIN, 1963: The social construction of natural troops of Japanese monkeys in $\mathrm{Ta}$ kasakiyama. Primates 4(3): 1-42.

ITANI et al. 1966: Population census of wild Japanese monkey in Takasakiyama. (Mimeograph)
KANO, K., 1964: On the second division of the natural troop of Japanese monkeys in Takasakiyama. In: J. ITANI et al ed. Wild Japanese monkeys in Takasakiyama, Keiso-Shobo. 42-73.

Kawai, M., S. Azuma, K. YoshibA, 1967 : Ecological studies of reproduction in Japanese monkeys (Macaca fuscata). I. Problems of the birth season. Primates. 8: 35-74.

KAWANAKA, K., 1968: Intertroop relations among Japanese monkeys. (unpublished $M$. Sc. Thesis, Kyoto Univ.)

Mizuhara, 1957: Japanese monkeys. SanichiShobo, 220pp.

1964: Social changes of Japanese monkeys in the Takasakiyama troop. Primates 5(1-2): 27-52.

, 1964-5: Make yourself a friend with monkey. (I-XI) Yaen No.18-31. 1971: History of the monkey land.

Sogensha, 25pp.

Nishid A, T., 1966: A sociological study of solitary male monkeys. Primates 7 : 141-204.

Nishimura, A., 1966: A report on the population size of monkeys at Takasakiyama. (Mimeograph) 
1966: A report on the birth of monkeys at Takasakiyama. (Mimeograph) 1966: A general report on monkeys at Takasakiyama (1965.4-1966.3). (Mimeograph)

, 1967: A report on the capture of troop D. (Mimeograph)

, 1969: Recent Takasakiyama. (Mimeograph)

Oita City (ed), 1967: Fifteen years of Takasakiyama Natural Park.

Sugiyama, Y., 1960: On the division of a natural troop of Japanese monkeys at Takasakiyama. Primates 2(2): 109-148. et al., 1964: Research report on the effect of the tunnel construction against monkeys at Takasakiyama. (I) 15pp. 1966: Research report on the effect of the tunnel construction against monkeys at Takasakiyama. (II) $14 \mathrm{pp}$. , 1966: Population dynamics of Japanese monkeys at Takasakiyama. Proc. 13th Jap. Soc. Ecol.: A206.

Toyoshima, A., 1968: On the third fusion of a Japanese monkey group at Takasakiyama. Proc. XIIIth Int. Congr. Anthrop. Ethnol. Sci. III : 287-288.

Yoshib A, K., 1965 : Takasakiyama today. Monkey $81: 30-33$.

(received August 1, 1973)

高崎山生息ニホンザルの個体群研究

増井憲一. 京都大学理学部自然人類学研究室

西邨顕達, 大沢秀行, 杉山幸丸. 京都大学霊長類研究所

高崎山生息の二ホンザル群は1953年餌付けされ，3回の群れ分裂を重ねて 4 群に增加した。最後の分裂群は 除去されたが，残りのA・B・C 各群は，880-900，250-260，250-260 頭と，いずれもこれまで知られている ヒト以外の霊長類の最大の群れとなった。個体数は 220 頭から 1400 頭に増加し, 現在もなお直線的な増加を続 けている．乙のような状態に扔けるニホンザルのポピュレーション・センサスの方法と, 1970-1972年の調査 結果をこの報告の主題とする. 今後, 継続調査の進行につれて, 個体群の動態を人口学的に検討してゆく. 